\title{
Los gestos de Cervantes: cuerpo y escritura
}

\author{
Adrián J. Sáez
}

"Aunque parezco padre, soy padrastro"1 y "yo soy aficionado a leer aunque sean los papeles rotos de las calles"2 son las sentencias de oro con las que Cervantes arma en dos tiempos el laberinto narrativo del Quijote, a la vez que cifra la clave de la literatura en el relato y — habría que añadir - en toda su obra ${ }^{3}$. Con toda la intención del mundo, la doble imagen tiene una cuidada apariencia autobiográfica que une fuertemente lectura y escritura, junto con el filtro adicional de la traducción que marca un antes y un después en la historia de la novela.

Se conocen bien las diversas caras del Cervantes lector ${ }^{4}$, así como sus ideas traductológicas ${ }^{5}$ y sus usos escriturales en el contexto cultural coetáneo ${ }^{6}$, pero

1 Miguel de Cervantes, Don Quijote de la Mancha, ed. Francisco Rico, 2 vols (Madrid, 2015), Prólogo. Este trabajo se ha beneficiado de una Mercator Fellowship en la Universidad de Heidelberg (SF B 933 "Materiale Textkulturen", marzo-junio de 2018) y se enmarca en los proyectos SILEM II: Biografías y polémicas: hacia la institucionalización de la literatura y el autor (RTI2018-095664-B-C21 del Ministerio de Economía y Competitividad, Gobierno de España) coordinado por Pedro Ruiz Pérez (Universidad de Córdoba) y vIEs: Vida y escritura I: Biografía y autobiografía en la Edad Moderna (FFI2015-63501-P) dirigido por Luis Gómez Canseco y Valentín Núñez Rivera (Universidad de Huelva). Se cita siempre por las ediciones consignadas en la bibliografía, con ocasionales retoques de ortografía y puntuación, y agradezco los comentarios del ingenioso José Manuel Martín Morán (Università del Piemonte Orientale).

2 Cervantes, Quijote, ed. Rico, I, 9.

3 Para la metáfora generativa, ver José Manuel Martín Morán, Cervantes y el "Quijote" hacia la novela moderna (Alcalá de Henares, 2009), pp. 17-51; y Clea Gerber, Genealogías literarias cervantinas: cuerpos y textos en el "Quijote" (Alcalá de Henares, 2018).

4 Margit Frenk, Entre la voz y el silencio (la lectura en tiempos de Cervantes) (Alcalá de Henares, 2001); Antonio Castillo Gómez, Leery oír: ensayos sobre la lectura en los Siglos de Oro (Madrid/ Fráncfort del Meno, 2016); Alberto Blecua, “Lecturas y plumas en Cervantes", en Aurea poesis: estudios para Begoña López Bueno, ed. Luis Gómez Canseco, Juan Montero y Pedro Ruiz Pérez (Huelva/Sevilla/Córdoba, 2014), pp. 229-240; y Sarah Malfatti, Lecturas y lectores: prácticas de lectura y comunidades interpretativas en el "Quijote" [en prensa].

5 Michel Moner, “Cervantes y la traducción”, Nueva Revista de Filología Hispánica 38. 2 (1990), 513-524; José Ramón Trujillo, "La traducción en Cervantes: lengua literaria y conciencia de autoría", Edad de Oro 23 (2004), 161-197.

6 Antonio Castillo Gómez, "La escritura representada: imágenes de lo escrito en la obra de Cervantes", en Volver a Cervantes: Actas del vi Congreso Internacional de la Asociación de Cervantistas (Lepanto, 1-8 de octubre de 20oo), ed. Antonio Bernat Vistarini (Palma de Mallorca, 2001), 1, pp. 311-325; id., 'Aunque sean los papeles rotos de las calles': cultura escrita y sociedad en el Quijote", Revista de Educación, núm. extraordinario (2004), 67-76; id., "Espejos de 